\title{
Blueberry Frost Protection Practices in Florida and Georgia ${ }^{1}$
}

\author{
Tatiana Borisova, Elizabeth Conlan, Erick Smith, Mercy Olmstead, and Jeffrey Williamson²
}

\section{Introduction}

In this publication, we examine freeze-protection decisions of blueberry growers in Florida and Georgia through responses to a producer survey. This information is intended to assist extension professionals to establish a benchmark for blueberry producers' use of freeze-protection practices. Changes in the practices over time (e.g., as a result of extension programs or technological advances) can then be evaluated against this benchmark.

Blueberry (Vaccinium spp.) acreage in Florida and Georgia has more than doubled over the past decade, driven largely by a system of early-season fruit production which includes low-chill, southern highbush (SHB) cultivars harvested at the beginning of the US blueberry season, from late March to early May (England 2015). However, due to early flowering, spring freeze injury is a widespread problem in the southeast (Strik and Yarborough 2005). For example, according to news reports, freezes in the 2016-2017 growing season "nearly wiped out" the Georgia blueberry industry, with up to 80 percent of the southern Georgia blueberry crop damaged (Collins 2017).

SHB cultivars flower in Florida during January and February and during February and March in Georgia, when damaging freezes often occur. As a result, freeze protection measures are commonly used to mitigate the risk of crop loss in Florida and Georgia (England 2015; NeSmith 2008). Producers commonly use dual irrigation systems, with overhead sprinkler irrigation being the most common method of freeze protection in the southeastern United States (Fonsah et al. 2007). Although the investment costs in an overhead irrigation system with a sprinkler output capacity sufficient for freeze protection can be high (Singerman et al. 2016), once a system is installed, operating costs are lower than that of active freeze protection alternatives like wind machines and heaters (Poling 2008). Potential downsides to sprinkler irrigation include evaporative cooling potentially exacerbating damage, ice accumulation on plants causing branches to break or stripping flowers off of twigs, and the large amounts of water needed (Perry 1998; Poling 2008; Snyder and Melo-Abreu 2005).

For recommendations regarding irrigation as a freeze protection strategy for blueberries, see UF/IFAS Extension publication HS968 by Williamson, Lyrene, and Olmstead at http://edis.ifas.ufl.edu/hs216.

\section{Survey Method Used in This Study}

We designed a survey to better understand frost protection decision-making for commercial blueberry growers in Florida and Georgia. Before distribution, the survey instrument was pre-tested by researchers in horticultural sciences and agricultural economics, Extension agents,

1. This document is FE1045, one of a series of the Food and Resource Economics Department, UF/IFAS Extension. Original publication date October 2018. Visit the EDIS website at https://edis.ifas.ufl.edu for the currently supported version of this publication.

2. Tatiana Borisova, associate professor and Extension specialist, Food and Resource Economics Department; Elizabeth Conlan, former student, Horticultural Sciences Department; Erick Smith, Department of Horticulture, University of Georgia; Mercy Olmstead, former associate professor, Horticultural Sciences Department; and Jeffrey Williamson, professor, Horticultural Sciences Department; UF/IFAS Extension, Gainesville, FL 32611. 
and growers. The Florida and Georgia blueberry surveys were reviewed by the University of Florida and University of Georgia Institutional Review Boards. All of the Florida blueberry surveys were distributed and collected at the Fall Blueberry Short Course of the Florida Blueberry Grower's Association in October 2015. In Georgia, surveys were administered and collected in collaboration with Extension at county meetings in southern Georgia between November 2015 and January 2016.

\section{Survey Results: Freeze Protection Decisions by Blueberry Producers CHARACTERISTICS OF THE SURVEY RESPONDENTS}

In total, we received 117 responses to the survey. After eliminating respondents who were not using active freeze protection or were not involved in major farm management decisions, 94 respondents remained, with 46 responses from Florida ( $48.9 \%$ of the total sample) and 51 responses from Georgia (51.1\% of the total sample). Note that some respondents did not provide answers to selected survey questions. As a result, the number of responses may vary among questions.

Respondents were provided with intervals representing various farm sizes, and taking the low-point for respondents' acreage response intervals, we estimate that the Florida and Georgia respondents manage about 1,696 acres and 2,850 acres respectively, or at least 37.7 percent and 19.0 percent of the total blueberry acreage in the two states. Note that these are conservative estimates of the sample representation, because they are based on the low bound of acreage response intervals and total blueberry acreage in the two states (as opposed to irrigated or freeze-protected acreage, for which no statistics exist).

Most of the producers who responded to the survey were experienced with blueberry production, with the average number of years in blueberry production being 10.1 years in Florida and 13.1 in Georgia. In both states, producers reported growing a mix of cultivars, with SHB varieties being the most prevalent (Table 1). 'Farthing' and 'Emerald' cultivars were popular in both states. In addition, a majority of respondents in Florida reported growing 'Jewel', while in Georgia, most producers were growing 'Star' (with 'Rebel' also being popular).

\section{USE OF FREEZE PROTECTION METHODS}

Of respondents who reported using at least one method of active freeze protection, almost all (98.9\%) used overhead irrigation for freeze protection (Table 2). The water source for overhead irrigation was statistically different between Florida and Georgia growers with the majority of Florida respondents using groundwater, whereas most Georgia respondents use on-farm ponds. Sprinkler type also varied by state; Georgia respondents primarily relied on impact sprinklers, whereas Florida respondents mostly used wobbler sprinklers.

\section{INFORMATION CONSIDERED IN FREEZE- PROTECTION DECISIONS}

Producers were asked to evaluate the importance of climatic and crop factors for the decision to initiate overhead irrigation for freeze protection (Table 3). Five factors identified in literature as important were presented to the growers, and all of them were predominately rated as important or very important, with expected duration of irrigation events being relatively less important.

Growers reported getting their weather information most regularly from on-farm weather systems or thermometers (Table 4). In Florida and Georgia, the Florida Automated Weather Network (FAWN) and Georgia Automated Environmental Monitoring Network (GAEMN), respectively, were used occasionally or regularly by approximately 90 percent of respondents. FAWN and GAEMN were created to provide weather data from areas throughout Florida and Georgia underserved by the National Weather Service, and their use by the growers illustrate the importance of these weather networks.

The top-ranked resource consulted when deciding to turn on overhead irrigation for freeze protection was other growers, with sixty-two percent of respondents (Table 5), supporting that the "train the trainer" approach to Extension programs, when Extension agents rely on communicating with the opinion leaders who then communicate with the rest of the farming community, is reasonable. Industry publications and Extension agents and websites were also consulted about overhead irrigation initiation by more than a fifth of growers. The most commonly listed sources of "other" information given by growers included personal experience, consultants, and weather stations.

\section{DECISIONS TO SWITCH FREEZE PROTECTION OVERHEAD IRRIGATION ON AND OFF}

Approximately one third of respondents (28.1\%) reported using dry bulb air temperature to determine when to use freeze protection ( $72.0 \%$ used wet bulb temperature), and significantly more growers in Florida reported using the dry bulb temp in overhead irrigation initiation (38.5\%, 
compared with $18.6 \%$ in Georgia, Chi-squared test, $\mathrm{p}$ $=0.05)$. Note that Extension materials on the critical temperatures for different bud stages are generally reported in dry bulb temperature, with advice and recommendations for calculating the wet bulb temperatures. To make the recommendations easier to follow, Extension agents can consider providing recommendations in both dry and wet bulb temperature, where possible.

The point at which growers decided to turn their systems on and off varied. For the sub-set of respondents who indicated using wet bulb temperature, Figure 1 shows that producers differ in their decisions about when to turn on their freeze protection systems. The differences between producers are especially noticeable for tight cluster and early pink stages, when some producers turn their systems on at $34^{\circ} \mathrm{F}-36^{\circ} \mathrm{F}$, while others do not protect. Interestingly, for these two bud stages, Florida and Georgia producers differed. For the tight cluster stage, the majority of Georgia responses in the sample were "do not protect" (66.7\%), whereas only $22.7 \%$ of respondents from Florida selected the same answer (Chi-squared test, $\mathrm{p}=0.05)$. Similarly, for early pink, $25.0 \%$ of the Georgia responses were "do not protect" compared to $4.8 \%$ of such responses in Florida.

The temperatures at which producers turn overhead irrigation for frost protection on and off (Figures 1 and 2) determine the duration of the irrigation event and, therefore, the frost-protection pumping costs and water use. However, some producers may consider the benefits of extending the duration of freeze-protection irrigation events to outweigh the costs. For example, they may account for the likelihood that irrigation system pipes will freeze (and hence, switching the irrigation system on earlier). Producers may also consider possible differences among the temperature measurements across the field, the risk of crop damage if the irrigation is turned off too early, or the potential labor and management costs of turning off the irrigation system early and then having to muster personnel to turn it on should the temperature drop again.

Overall, the responses show significant differences in choices made by producers faced with the same types of frost-protection decisions. The number of events also differed significantly among producers. For example, in the season preceding the survey (the 2014-2015 season), on average, growers activated overhead irrigation for frost protection 5 times, with a range of zero to twenty times during the season (Figure 3 ). This difference cannot solely be attributed to the differences in local climate. For example, the survey included 14 responses from Clinch County producers (Georgia). And for this small geographical area, producers turned their freeze protection systems on from 3 to 18 times in the 2014-2015 production season. Similarly, for 8 respondents from Polk County (Florida), the reported range of producers turning their freeze-protection system on was from 1 to 12 times. Based on existing literature, the decisions regarding freeze protection are guided by producers' aversion to risk and access to geographically relevant and accurate weather forecasts (Crane et al. 2010; $\mathrm{Hu}$ et al. 2006; Klockow et al. 2010; Kusunose and Mahmood 2016; Mase and Prokopy 2014; Stewart et al. 1984). Providing producers with information and tools to make freeze-protection decisions to protect their crops while also reducing their water and pumping costs should be a priority for outreach specialists.

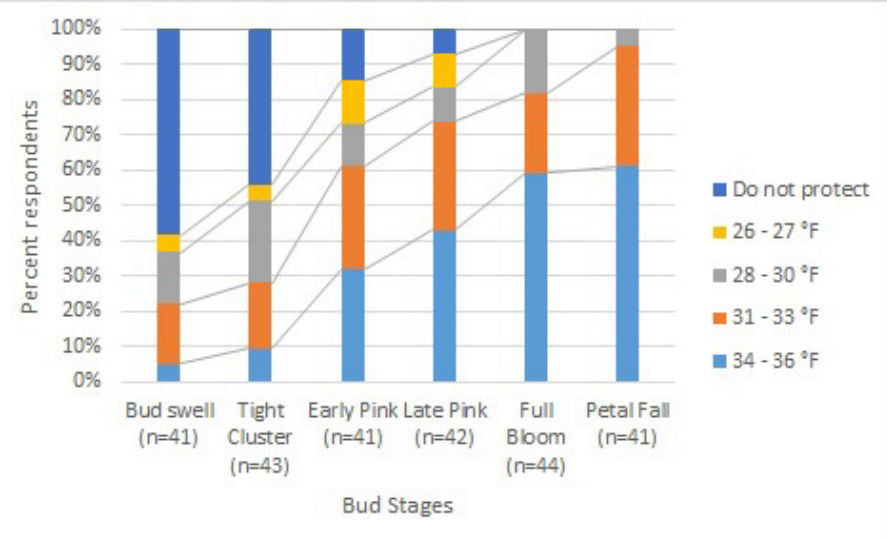

Figure 1. Responses to the question "For the following bud stages, for nights where the temperature is predicted to drop below freezing $\left(32^{\circ} \mathrm{F}\right)$, please select the air temperature $\left({ }^{\circ} \mathrm{F}\right)$ at which you turn on your irrigation system for freeze protection" (all respondents to this question indicated they used wet bulb temperature to determine when to use freeze protection).

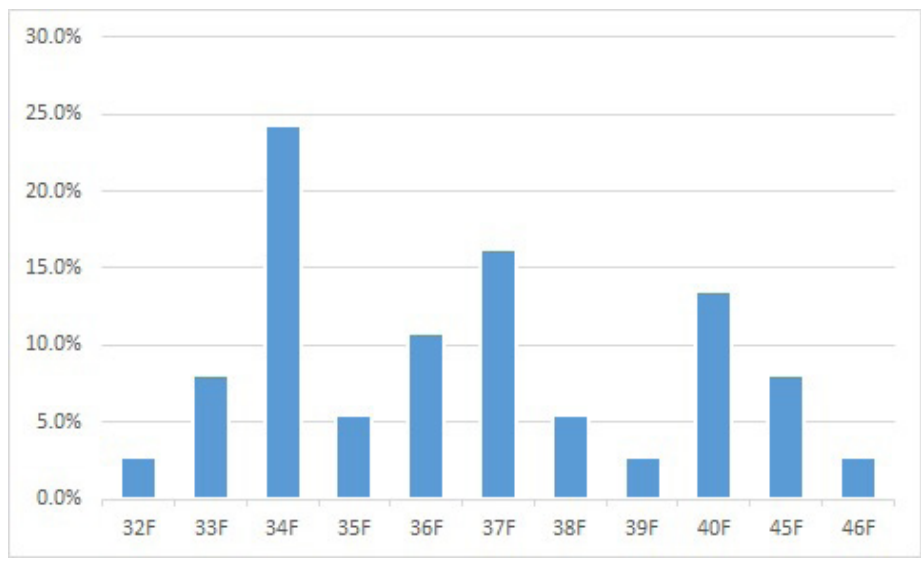

Figure 2. Responses to the question "What air temperature $\left({ }^{\circ} \mathrm{F}\right)$ do you consider to be critical for turning off your irrigation system?" (all respondents to this question indicated they used wet bulb temperature to determine when to use freeze protection, $\mathrm{N}=37$ ). 


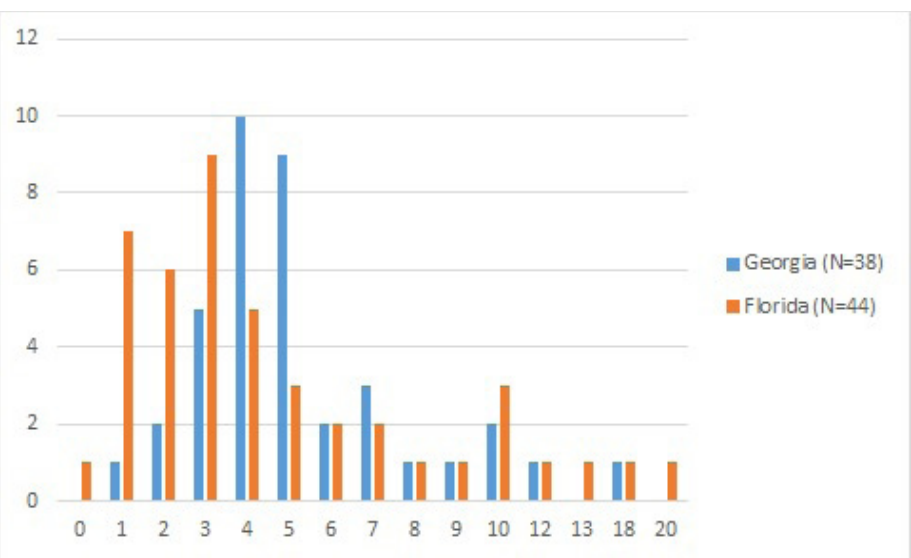

Figure 3. The number of times blueberry growers in Georgia and Florida reported activating irrigation for freeze protection last production season (2014-2015).

\section{ESTIMATING REDUCTIONS IN PUMPING COSTS AND WATER USE FOR CHANGING FREEZE PROTECTION DECISIONS}

Most producers reported using diesel pumps (though in Georgia, a relatively large proportion of producers also used electric pumps; Table 6). Producers also reported having approximately one pump per 20-25 acres (though the number of pumps varies from producer to producer).

Generally, overhead irrigation rate used by producers is 0.25 to 0.3 inches per hour. With overhead irrigation rate of 0.3 inches per hour, the total water application rate per hour for 20 acres served by one pump is 162,872 gallons of water per pump per hour. Given that the mean number of overhead irrigation events reported for the 2014-2015 production season was 5 , adjusting the temperature for turning the overhead irrigation system on/off to save one hour per event would save 5 hours ${ }^{*} 162,872$ gallons $=814,360$ gallons per pump per season. Given the approximate farm diesel costs of $\$ 21.25$ per pump per hour (Borisova et al. 2015), such a change in practice can save producers $\$ 106.25$ per pump per season. While the monetary savings may be modest, savings in water are significant. Note, however, that irrigation can be considered a really cheap "insurance" for the grower against frost losses (compare the irrigation cost with the total profit of $\$ 25,000-\$ 35,000$ per acre).

\section{Concluding Remarks}

The blueberry freeze protection survey described in this publication provides information about freeze-protection irrigation use by Florida and Georgia blueberry producers. Specifically, it identifies that overhead irrigation is the most popular method of active freeze protection among blueberry producers in both Florida and Georgia, with sprinkler head type differing between the two states. An absolute majority of producers believed that air temperature, dew point, wind speed, and bud stages were very important for their decision to activate overhead irrigation for freeze protection with expected duration of irrigation events being relatively less important. On-farm weather systems and thermometers, as well as FAWN and GAEMN readings and advice from other producers, are typically used to make decisions regarding freeze protection. The top-ranked resource growers consulted when deciding to turn on overhead irrigation for freeze protection was other growers, with Extension and industry resources also being used.

At the same time, decisions about freeze protection varied significantly among respondents. Producers' decisions to freeze-protect at specific bud stages, their choices about the number of times to freeze-protect during a specific season, and their decisions about the temperatures that necessitated engaging and disengaging freeze-protection irrigation varied greatly. These differences potentially translate into significant differences in water use on one hand, and irrigation costs and, potentially, effectiveness of freeze-protection irrigation on the other hand. These differences also indicate a need for improved information regarding freeze-protection irrigation to improve precision of the practice.

The survey results provide a baseline of irrigation freeze protection against which to compare future intervention, such as the dissemination of more precise overhead irrigation recommendations. Additional information about critical bud temperatures for each blueberry floral bud stage, especially for southern highbush cultivars, could help blueberry producers to better tailor their frost-protection strategies to Florida and Georgia climate. Some blueberry growers in Florida are being overly cautious with earlier blueberry bud stages, choosing to freeze-protect when the temperature hits freezing. Improved information regarding the need to freeze-protect when the buds are at the dormant-tight cluster stage (1-2), could help such producers reduce their frost protection irrigation costs and their water consumption, without reducing the effectiveness of the frost protection practices.

\section{Acknowledgements}

This research was supported by the Florida Department of Agriculture \& Consumer Services Specialty Crop Block Grant. 


\section{References}

Borisova, T., T. Bradley, M. Olmstead, and J. Williamson. 2015. Improving the Precision of Blueberry Freeze Protection Irrigation. FE979. Gainesville: University of Florida Institute of Food and Agricultural Sciences. http://edis.ifas.ufl.edu/ fe 979

Collins, J. 2017. "Deep South freeze means fewer blueberries and peaches." Associated Press. March 20, 2017. https:// apnews.com/4b994210cec34a028fe3bb746437fd59

Crane, T., C. Roncoli, J. O. Paz, N. Breuer, K. Broad, K. Ingram, and G. Hoogenboom. 2010. "Forecast skill and farmers' skills: Seasonal climate forecasts and agricultural risk management in the southeastern United States." Weather Climate Soc. 2:44-59.

England, G. 2015. "An Overview of the Blueberry Industry in Florida." Journal of the American Pomological Society, 69(1) 2-3.

Fonsah, E.G., G. Krewer, K. Harrison, and M. Bruorton. 2007. "Risk-rated economic return analysis for southern highbush blueberries in soil in Georgia." HortTechnology 17(4):571-579.

Hu, Q., L. M. Pytlik Zillig, G. Lynne, A. Tomkins, W. Waltman, M. Hayes, K. Hubbard, I. Artikov, S. Hoffman, and D. Wilhite. 2006. "Understanding farmers' forecast use from their beliefs, values, social norms, and perceived obstacles." J. Appl. Meteorol. Climatol. 45:1190-1201.

Klockow, K. E., R. A. McPherson, and D. S. Sutter. 2010. "On the economic nature of crop production decisions using the Oklahoma Mesonet." Weather Climate Soc. 2:224-236.

Kusunose, Y., and R. Mahmood. 2016. "Imperfect forecasts and decision making in agriculture." Agr. Systems 146:103-110.

Mase, A. S. and L. S. Prokopy. 2014. "Unrealized potential: A review of perceptions and use of weather and climate information in agricultural decision making." Weather Climate Soc. 6:47-61.

NeSmith, D. S. 2008. “'Rebel' Southern Highbush Blueberry.” HortScience 43(5):1592-1593.

Patten, K., E. Neuendorff, G. Nimr, J. R. Clark, and G. Fernandez. 1991. "Cold injury of southern blueberries as a function of germplasm and season of flower bud development." HortScience 26:18-20.

Perry, K. B. 1998. "Basics of freeze and freeze protection for horticultural crops.” HortTechnology 8(1):10-15.

Poling, E. B. 2008. "Spring cold injury to winegrapes and protection strategies and methods." HortScience 43(6):1652-1662.

Singerman, A., M. Burani-Arouca, J. G. Williamson, and G. K. England. 2016. Establishment and Production Costs for Southern Highbush Blueberry Orchards in Florida: Enterprise Budget and Profitability Analysis. FE1002. Gainesville: University of Florida Institute of Food and Agricultural Sciences. https://edis.ifas.ufl.edu/fe1002

, Food and Agriculture Organization of the United Nations, Rome, pp.1-240.

Spiers, J. M. 1978. "Effect of stage of bud development on cold injury in rabbiteye blueberry." Journal of the American Society for Horticultural Science 103(4):452-455.

Stewart, T. R., R. W. Katz, and A. H. Murphy. 1984. "Value of weather information: A descriptive study of the fruitfrost problem." Bul. of the Amer. Meteorol. Soc. 65:126-137.

Strik, B. C., and D. Yarborough. 2005. "Blueberry production trends in North America, 1992 to 2003, and predictions for growth." HortTechnology 15(2):391-398.

Williamson, J. G., P. M. Lyrene, and J. W. Olmstead. 2015. Protecting Blueberries from Freezes in Florida. HS968. Gainesville: University of Florida Institute of Food and Agricultural Sciences. http://edis.ifas.ufl.edu/hs216 
Table 1. Percent Respondents who indicated growing specific cultivars, by state $(\mathrm{N}=93)$.

\begin{tabular}{|l|c|c|c|}
\hline \multicolumn{1}{|c|}{ Variety } & Florida & Georgia & Total sample \\
\hline Farthing & $55.6 \%$ & $70.8 \%$ & $63.4 \%$ \\
\hline Emerald & $93.3 \%$ & $64.6 \%$ & $78.5 \%$ \\
\hline Jewel & $71.1 \%$ & $2.1 \%$ & $35.5 \%$ \\
\hline Meadowlark & $53.3 \%$ & $37.5 \%$ & $45.2 \%$ \\
\hline Rebel & $6.7 \%$ & $50.0 \%$ & $29.0 \%$ \\
\hline San Joaquin & $2.2 \%$ & $8.3 \%$ & $5.4 \%$ \\
\hline Star & $15.6 \%$ & $91.7 \%$ & $54.8 \%$ \\
\hline Other & $73.3 \%$ & $29.2 \%$ & $50.5 \%$ \\
\hline
\end{tabular}

Table 2. Percent of blueberry growers in Florida and Georgia who use various active freeze-protection methods.

\begin{tabular}{|c|c|c|c|c|}
\hline State & Irrigation & Wind Machines & Cover & Heat \\
\hline Florida ( $N=46)$ & $97.8 \%$ & $2.2 \%$ & $4.4 \%$ & $0.0 \%$ \\
\hline Georgia (N = 48) & $100.0 \%$ & $10.4 \%$ & $0.0 \%$ & $0.0 \%$ \\
\hline Total sample $(N=94)$ & $98.9 \%$ & $6.4 \%$ & $2.1 \%$ & $0.0 \%$ \\
\hline
\end{tabular}

Table 3. Importance of five factors in the decision to activate an overhead irrigation system for freeze protection according to Florida and Georgia blueberry growers.

\begin{tabular}{|l|c|c|c|c|c|c|}
\hline \multicolumn{1}{|c|}{ Factors } & $\begin{array}{c}\text { Number of } \\
\text { responses }\end{array}$ & Not Important & $\begin{array}{c}\text { Of Little } \\
\text { Importance }\end{array}$ & $\begin{array}{c}\text { Moderately } \\
\text { Important }\end{array}$ & $\begin{array}{c}\text { Important } \\
\text { Important }\end{array}$ \\
\hline Air temperature & 86 & $0.0 \%$ & $0.0 \%$ & $0.0 \%$ & $22.1 \%$ & $77.9 \%$ \\
\hline Dew point & 89 & $1.1 \%$ & $3.4 \%$ & $4.5 \%$ & $16.9 \%$ & $74.2 \%$ \\
\hline Wind speed & 88 & $0 \%$ & $1.1 \%$ & $2.3 \%$ & $79.3 \%$ & $13.8 \%$ \\
\hline Bud stage & 87 & $0 \%$ & $0 \%$ & $1.2 \%$ & $85.1 \%$ \\
\hline $\begin{array}{l}\text { Expected duration of the } \\
\text { freeze/freeze event }\end{array}$ & 81 & $3.7 \%$ & $6.2 \%$ & & $23.9 \%$ & \\
\hline
\end{tabular}

Table 4. For the producers who use active freeze protection. Frequency of weather information obtained by surveyed Florida and Georgia blueberry growers from four weather sources. The Florida Automated Weather Network (FAWN) was listed on Florida surveys and Georgia Automated Environmental Monitoring Network (GAEMN) was listed on Georgia surveys.

\begin{tabular}{|c|c|c|c|c|c|}
\hline Weather Sources & $\mathbf{N}$ & Never & Rarely & Occasionally & Regularly \\
\hline On-farm weather system / thermometers & 79 & $5.1 \%$ & $3.8 \%$ & $10.1 \%$ & $81.0 \%$ \\
\hline $\begin{array}{l}\text { Florida Automated Weather Network (FAWN) / } \\
\text { Georgia Automated Environmental Monitoring } \\
\text { Network (GAEMN) }\end{array}$ & 84 & $7.1 \%$ & $2.4 \%$ & $19.1 \%$ & $71.4 \%$ \\
\hline $\begin{array}{l}\text { National Oceanic and Atmospheric } \\
\text { Administration (NOAA) }\end{array}$ & 74 & $21.7 \%$ & $6.8 \%$ & $28.4 \%$ & $43.2 \%$ \\
\hline The Weather Channel & 82 & $20.7 \%$ & $2.4 \%$ & $26.8 \%$ & $50.0 \%$ \\
\hline Other & 48 & $10.4 \%$ & $8.3 \%$ & $25.0 \%$ & $56.3 \%$ \\
\hline
\end{tabular}


Table 5. Percentage of Florida and Georgia blueberry growers who use various information sources when deciding to activate an overhead irrigation system for freeze protection $(\mathrm{N}=86)$.

\begin{tabular}{|l|c|}
\hline \multicolumn{1}{|c|}{ Information Source } & Percentage Consulting \\
\hline Advice from other growers & 67.4 \\
\hline Extension, including: & $39.5^{*}$ \\
\hline Extension agents & 22.1 \\
\hline Extension website & 23.3 \\
\hline Industry publications & 27.9 \\
\hline * combined responses related to agents, website, and other extension products & \\
\hline
\end{tabular}

Table 6. Types of pumps used.

\begin{tabular}{|l|l|c|c|}
\hline \multicolumn{1}{|c|}{ State } & diesel & electric & both \\
\hline Florida $(\mathbf{N}=\mathbf{4 4})$ & & $79.6 \%$ & $6.8 \%$ \\
\hline Georgia $(\mathbf{N}=\mathbf{4 9})$ & $59.2 \%$ & $28.6 \%$ & $13.6 \%$ \\
\hline Total sample $(\mathbf{N}=\mathbf{9 3})$ & $\mathbf{6 8 . 8} \%$ & $\mathbf{1 8 . 3} \%$ & $12.2 \%$ \\
\hline
\end{tabular}

